\title{
CONTROL OF WEEDS BY PAPER MULCH IN VEGETABLES AND TREES
}

\author{
K.C. HARRINGTON and T.A. BEDFORD \\ Institute of Natural Resources, Massey University, PB 11-222, Palmerston North \\ Corresponding author: K.Harrington@massey.ac.nz
}

\begin{abstract}
A commercially available paper mulch (EcoCover) was assessed for its persistence under field conditions and its ability to control weeds in vegetable crops and establishing trees. Weeds were controlled as effectively by EcoCover in autumn-planted cabbage and lettuce crops as by black polythene mulches. The paper mulch was beginning to break down by the time the crop was harvested. Paper mulch that was buried decayed much faster than when left on the soil surface. EcoCover was compared with residual herbicides, black weed mat and another paper mulch (Korromatt) for controlling weeds under trees planted in spring. Both types of paper mulch were prone to being dislodged by wind at exposed sites, but otherwise provided weed control for about 6 months after being laid. The potential uses of paper mulches for weed control in New Zealand are discussed.
\end{abstract}

Keywords: mulches, weed control, cabbage, lettuce, tree establishment.

\section{INTRODUCTION}

Mulches have been used for many years to prevent weeds from establishing in crops by covering the soil with a material that blocks light from weed seeds, resulting in them remaining dormant (Morgan 1989). Any seeds that do germinate usually die, as the seedling cannot penetrate the mulch to begin photosynthesising. Materials used for mulches include bark, sawdust, straw, black polythene and black plastic woven weed mat (Ingle \& Bussell1988; Hartley \& Rahman 1994). They vary greatly in characteristics such as costs, nitrogen immobilisation, permeability to rainfall, influence on soil temperature, adding organic matter to the soil, and disposal problems once crops have been harvested (Carter \& Johnson 1988).

Several mulch products have been released recently on to the market that make use of recycled paper, and this study investigates the weed control characteristics of one such product, produced in Auckland, and marketed and patented as EcoCover. It is comprised of shredded waste paper glued between two sheets of brown paper, and has been accepted by AgriQuality as a permissible product for weed control in their Certenz organic farming certification system (M. Cruickshank, pers. comm.).

\section{Trial 1}

\section{MATERIALS AND METHODS}

Two vegetable crops were grown using EcoCover mulch and compared with crops grown with either black polythene or infrequently cultivated bare soil at the Fruit Crops Unit of Massey University, Palmerton North. Each plot was comprised of a $6 \mathrm{~m}$ long and $1 \mathrm{~m}$ wide bed that was prepared on a Manawatu fine sandy loam. The beds were either covered by $1 \mathrm{~m}$ wide strips of black polythene or EcoCover mulch or left uncovered (control treatment). Soil was used to hold the mulch material in place along the edges. A randomised block design with three replicates was used. On 16 May 2003, one end of each plot was planted with cabbage seedlings (cv. Emerald) and the other end planted with lettuces (cv. Impact), using two rows of plants $30 \mathrm{~cm}$ apart and with $40 \mathrm{~cm}$ spacings within the rows. As weed growth was slow over winter, the bare soil plots were hoed 
only once during the trial, on 30 September 2003. Weed growth in the plots was assessed by counting numbers of plants within the plots on 26 June 2003, using five $30 \mathrm{~cm} \times 20 \mathrm{~cm}$ quadrats per plot for bare soil treatments, and assessing the entire plots for the mulch treatments. Weed dry weight (DW) was also estimated on 29 September 2003 by cutting weeds at ground level from two $0.06 \mathrm{~m}^{2}$ quadrats per plot. Crop yields were estimated on 23 October 2003 for the lettuces and 7 November 2003 for the cabbages by measuring the fresh weight $(\mathrm{FW})$ of the six largest plants from each plot. Only the largest plants were measured as rabbits and birds had damaged some of the smaller plants.

\section{Trial 2}

To estimate how rapidly EcoCover decomposes when buried after a crop is harvested, the residual weight was compared over time for mulch left on the soil surface relative to buried mulch. Strips of EcoCover $30 \mathrm{~cm}$ x $50 \mathrm{~cm}$ were either pinned to the surface of bare soil on 26 June 2003 or buried under $9 \mathrm{~cm}$ of Manawatu fine sandy loam soil at the Frewens Pasture and Crop Research Unit at Massey University. Wire cages covered all strips to prevent damage from rabbits, and herbicide was occasionally applied to prevent the site being infested with weeds. At monthly intervals, five buried strips and five surface strips were carefully cleaned of soil particles, dried at $80^{\circ} \mathrm{C}$ and weighed.

\section{Trial 3}

The ability of EcoCover to keep weeds from establishing around young trees was compared with other control strategies on hill country at the Haurongo Sheep and Beef Cattle Research Unit of Massey University near Palmerston North. Pine seedlings (Pinus radiata) were planted into recently grazed pasture in July 2003. Squares of mulch $1 \mathrm{~m}^{2}$ were pinned around some of the trees, using EcoCover, Korromatt (a commercial mulch similar in structure to corrugated cardboard) and black woven weed mat. Half of the trees with EcoCover or black weed mat and all Korromatt mats had vegetation killed around the trees before laying using a haloxyfop/clopyralid (Gallant NF/Versatill) mixture (equivalent to $0.6 \mathrm{~kg}$ ai/ha of each compound). Mulches were laid on 12 September 2003, with EcoCover mulches averaging $700 \mathrm{~g} / \mathrm{m}^{2}$ and Korromatt weighing $370 \mathrm{~g} / \mathrm{m}^{2}$.

These treatments were compared with two herbicide treatments with $1 \mathrm{~m}^{2}$ patches around each tree. One treatment involved a terbuthylazine/hexazinone mixture (AgPro Valzine 500 ) equivalent to 7.3 and $1.3 \mathrm{~kg}$ ai/ha respectively of the compounds applied on 19 August 2003. For the other treatment, vegetation was initially removed on 19 August 2003 with the haloxyfop/clopyralid mixture used for some mulch treatments, and this was followed by shielded spot-spraying with a paraquat/diquat/clopyralid mixture (Preeglone/Versatill) at $0.62 / 0.37 / 0.30 \mathrm{~g}$ ai/litre of spray mix respectively on 22 October 2003 .

All treatments were applied to 12 different trees using a randomised block design. The height of trees was measured on 22 September 2003 and 5 March 2004. The proportion of the ground still covered by mulches was estimated at regular intervals after the initial laying. The amount of vegetation growing within the treated $1 \mathrm{~m}^{2}$ area at the base of each tree was estimated proportional to untreated ground on 5 March 2004.

Data collected from all three trials was subjected to an analysis of variance.

\section{Trial 1}

\section{RESULTS AND DISCUSSION}

As expected, the two mulch treatments greatly reduced the number and weight of weeds that established in the lettuce and cabbage crops (Table 1). Less weeds established in the EcoCover plots than the black polythene plots because the EcoCover folded back down into the planting holes much better than the polythene, allowing fewer weeds to establish within the planting holes. Although small holes were appearing in the EcoCover due to decomposition by the time the crops were ready for harvest, weed control was still excellent. The crop yield from the EcoCover plots was as good as from the black polythene plots (Table 1). 
TABLE 1: Weed control and crop yield for lettuce and cabbage crops planted in May 2003 under mulch treatments or bare ground. Means within rows sharing the same letters are not significantly different $(\mathbf{P}<0.05)$ (Trial 1).

\begin{tabular}{lccc}
\hline & $\begin{array}{c}\text { EcoCover } \\
\text { mulch }\end{array}$ & $\begin{array}{c}\text { Black } \\
\text { polythene }\end{array}$ & $\begin{array}{c}\text { Bare } \\
\text { soil }\end{array}$ \\
\hline No. weeds $/ \mathrm{m}^{2}$ after 6 weeks & $9.7 \mathrm{a}$ & $20.8 \mathrm{~b}$ & $761.0 \mathrm{c}$ \\
Weed DW $\left(\mathrm{g} / \mathrm{m}^{2}\right)$ after 19 weeks & $2.1 \mathrm{a}$ & $5.9 \mathrm{a}$ & $280.3 \mathrm{~b}$ \\
Lettuce FW $(\mathrm{g} / \mathrm{plant})$ after 23 weeks & $480 \mathrm{~b}$ & $550 \mathrm{~b}$ & $170 \mathrm{a}$ \\
Cabbage FW (g/plant) after 25 weeks & $1170 \mathrm{~b}$ & $1120 \mathrm{~b}$ & $560 \mathrm{a}$ \\
\hline
\end{tabular}

\section{Trial 2}

For EcoCover mulch laying on the soil surface in Trial 2, there was a steady decline in biomass over the eight months that measurements were made (Fig. 1). However, it was not until about 7 months after the trial commenced that holes began appearing in the mulch allowing weeds to emerge. Conversely, mulch material that was buried began to decompose very rapidly, and no further measurements were possible after 3 months as the material had disintegrated too much to allow the mulch to be removed from the soil (Fig. 1). Even after 1 month, the buried material was soft and permeable enough to allow roots to penetrate through it, suggesting it would be no impediment for crop growth should it be ploughed under and another crop grown on it.

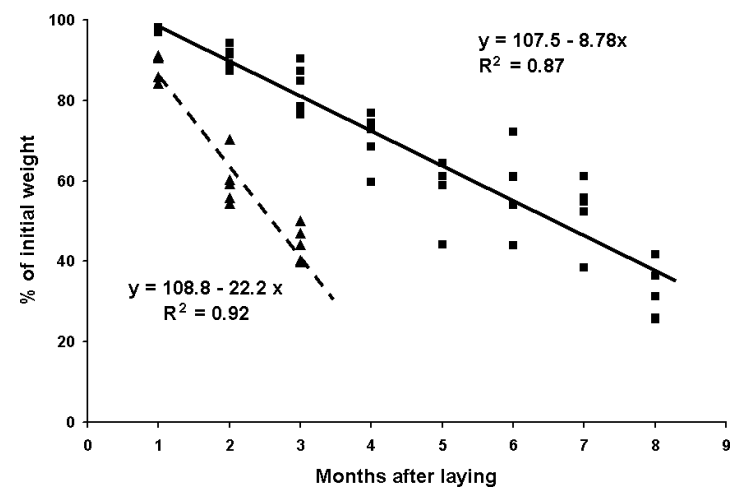

FIGURE 1: The decay of EcoCover strips laid on the soil surface (squares) or buried $9 \mathrm{~cm}$ deep (triangles). The lines are the regressions fitted to the residual masses. The slopes of these lines are significantly different at $P<0.01$.

\section{Trial 3}

Generally the EcoCover mulch was able to provide good control of weeds around the establishing trees. It was as effective as the black weed mat at suppressing and killing plants left unsprayed around the base of trees, though the species present were mainly easily-killed perennial grasses such as browntop (Agrostis capillaris) and Yorkshire fog (Holcus lanatus). In a few situations, Californian thistle (Cirsium arvense) was present, and this was able to penetrate up through the paper mulch. The black weed mat was superior to the two types of paper mulch at withstanding the strong winds at the exposed trial site. Once the paper mulches were wet, they became susceptible to being ripped from the pins and blown away. This happened with $29 \%$ of the EcoCover plots and $42 \%$ of the Korromatt plots, whereas no black weed mats were dislodged. If the paper mulches withstood the winds, they were still providing good weed control after 25 weeks, though 
holes were appearing in them by this stage due to decomposition. Although only $60-80 \%$ of the ground was still covered by the paper mulches after 25 weeks (Table 2), this was due to dislodgement by wind rather than decomposition. Weeds had established wherever mulch was no longer intact. Weeds had also grown in the plots initially cleared with non-residual herbicides, and in the plots with terbuthylazine and hexazinone (Table 2), mainly because of the tolerance of creeping buttercup (Ranunculus repens) to these triazine herbicides.

TABLE 2: Ground cover ( $\%$ ) by mulch treatments at 25 weeks after laying, weed growth (\% biomass relative to untreated ground) and the increase in tree height for various mulch and herbicide treatments around young trees in Trial 3.

\begin{tabular}{lccc}
\hline & $\begin{array}{c}\text { Ground cover } \\
\text { by mulch } \\
(\%)\end{array}$ & $\begin{array}{c}\text { Biomass } \\
\text { relative to } \\
\text { untreated }(\%)\end{array}$ & $\begin{array}{c}\text { Tree height } \\
\text { (as \% of } \\
\text { initial height) }\end{array}$ \\
\hline bare soil & - & 89 & 169 \\
hexazinone + terbuthylazine & - & 39 & 196 \\
unsprayed EcoCover & 83 & 19 & 176 \\
sprayed EcoCover & 63 & 45 & 159 \\
unsprayed black mat & 100 & 2 & 191 \\
sprayed black mat & 100 & 1 & 171 \\
sprayed Korromatt & 60 & 33 & 143 \\
\hline LSD $(\mathrm{P}=0.05)$ & 22 & 23 & 39 \\
\hline
\end{tabular}

There was little impact of weed control method on growth in tree height after 25 weeks, partly due to variability in tree size and partly due to the relatively short amount of time involved. Presumably the plots with high biomass would have less tree growth if these weeds were permitted to grow unchecked. The black weed mat looked most likely to provide the best long-term weed control.

Normally mulches would be expected to improve water relations under trees over summer, but this summer was a very wet one in Manawatu, especially in February 2004 when $303 \mathrm{~mm}$ was recorded.

\section{CONCLUSIONS}

As costs for mulches are approximately $\$ 1.00, \$ 3.00$ and $\$ 4.00$ per square metre for black weed mat, Korromatt and EcoCover respectively, they are more expensive than herbicide options. For example, treating cabbages with both alachlor and trifluralin would cost 1.2 cents per square metre. Treating the base of trees with haloxyfop, clopyralid and terbuthylazine would cost 5.2 cents per square metre. For the base of establishing trees, black weed mat is the most cost effective strategy if mulches were used, although EcoCover offers the advantage of not having plastic left around trees once they are established. Paper mulches such as EcoCover probably have most potential for use in short-term high value row crops such as cut flowers and organic herbs where selective herbicides are not available or cannot be used. Its biodegradable nature allows it to be cultivated under the soil once the crop is harvested, whereas polythene has to be removed for disposal.

\section{REFERENCES}

Carter, J.; Johnson, C. 1988: Influence of different types of mulches on eggplant production. HortScience 23: 143-145.

Hartley, M.J.; Rahman, A. 1994: Use of mulches and herbicides in an apple orchard. Proceedings $47^{\text {th }}$ NZ Plant Protection Conf.: 320-324.

Ingle, A.; Bussell, W.T. 1988: Mulches for weed control in asparagus and kiwifruit. Proceedings $41^{\text {st }}$ NZ Weed and Pest Control Conf.: 57-60.

Morgan, W.C. 1989: Alternatives to herbicides. Plant Prot. Quart. 4: 33-37. 